\title{
Workshop on Proposal and Classroom Action Research Report for Primary School Teachers in Pasaman District, West Sumatera
}

\author{
Relsas Yogica, Renol Afrizon, Defri Ahmad, Eka Yusmaita \\ Universitas Negeri Padang \\ Universitas Negeri Padang, Jl. Prof. Dr. Hamka Air Tawar Barat, Padang Utara, Kota Padang, 25131, Indonesia \\ * Correspondence: relsasyo @ fmipa.unp.ac.id; Tel.: +62-852-742-63829
}

Diterima 8 Oktober 2019, Disetujui 21 Oktober 2019, Dipublikasikan 30 November 2019

\begin{abstract}
Classroom action research has the character to find and solve problems in the learning process. By conducting action research the ability of teachers to master classroom conditions will increase, so that students' understanding of material will increase. Further impact, students' interest in learning will increase rapidly. But there are still many teachers who are unable to carry out this action research. In Pasaman District, this problem arose. Action is needed to train teachers to be able to carry out classroom action research. We have carried out community service in the form of workshops on making proposals and preparing research reports for teachers. We carry out activities for 1 month, in accordance with the agreement of the team, the school principal and the district head. The workshop was held at Pasaman $23^{\text {rd }}$ Public Elementary School. Participants are teachers from several schools, as many as 40 people. The workshop instructor is a Classroom Action Research expert. Based on the satisfaction questionnaire, we learned that the workshop material had increased teacher understanding, a score of 92.24. The workshop method has trained the teacher's ability, a score of 89.66. Workshop techniques have improved the quality of learning and improved teacher skills, a score of 93.10. Finally, the workshop product has increased the teacher's understanding of classroom action research, a score of 93.10. Based on these data it was concluded that the overall workshop implementation had improved teacher competency.
\end{abstract}

Keywords - workshop, proposal, report, action research

\section{Pendahuluan}

Matematika dan IPA merupakan bidang ilmu yang menjadi dasar bagi seorang siswa dalam mempelajari sains. Pembelajaran matematika dan IPA disebutkan sebagai pelayan ilmu pengetahuan lainnya[1] dan mengutamakan pola pikir yang sistematis[2]. Jika dasar ini kurang bagus, siswa akan kesulitan untuk memahami pengembangannya[3], bahkan buruknya siswa akan kesulitan dalam mempelajari sains lain. Kemampuan yang lemah ini, tidak terlepas dari pemahaman siswa terhadap matematika dan IPA di sekolah dasar.

Pemahaman siswa yang baik ditentukan oleh situasi pembelajaran yang kondusif. Situasi pembelajaran yang kondusif dapat diwujudkan karena peran seorang guru dan siswa[4], karena hakikatnya pembelajaran tidak hanya sebagai media untuk transfer informasi, namun juga menciptakan suasana kelas yang kondusif[5]. Guru yang mampu memahami kondisi dan situasi kelasnya merupakah gambaran guru yang profesional[6]. Untuk memahami kondisi dan situasi tersebut, seorang guru harus dapat melaksanakan penelitian tindakan kelas, yakni guru melakukan kegiatan ilmiah dengan mengikuti alur pikir akademik dan bisa dipertanggungjawabkan secara ilmiah. Penelitian tindakan kelas akan membentuk guru profesional dan mampu meningkatkan mutu pembelajaran[7]. Selain itu, guru akan terbiasa untuk berfikir 
reflektif, mampu mengetahui kelemahan sendiri dan mampu mencari antisipasi dalam tindakan berikutnya. Penelitian tindakan kelas juga dapat menjadi kunci untuk penyelesaian masalahmasalah pembelajaran[8].

Permasalahan yang dialami guru di beberapa sekolah adalah kurangnya kemampuan untuk melaksanakan penelitian tindakan kelas secara ilmiah. Maksudnya adalah kemampuan untuk mendokumentasikan kegiatan penelitian, antara lain kemampuan untuk membuat proposal dan laporan penelitian. Alasan kuat penyebab hal ini terjadi adalah kurangnya pengetahuan guru[9]. Salah satu kecamatan di Indonesia yang gurunya mengalami masalah ini adalah Kecamatan Pasaman, Sumatera Barat. Akibat permasalahan ini adalah minat siswa menjadi lemah. Minat siswa yang rendah, akan menyebabkan partisipasi dalam pembelajaran juga menjadi rendah[10]. Dengan adanya penelitian tindakan kelas, kemampuan guru terhadap penguasaan kelas guna menciptakan pembelajaran yang berkualitas akan meningkat. Hal ini, akan berimbas pada minat belajar siswa, karena guru yang mampu mengelola kelas dengan baik dapat meningkatkan semangat dan minat siswa dalam belajar.

Keadaan buruk tidak mungkin didiamkan tanpa dicarikan jalan keluarnya. Pihak sekolah membutuhkan bantuan penyelesaian masalah lemahnya kemampuan guru ini, dalam bentuk pelaksanaan workshop pembuatan proposal dan laporan tindakan kelas. Sehingga tim pengabdian menyediakan kesempatan kepada guru untuk belajar melalui workshop. Workshop merupakan suatu kegiatan penyelesaian masalah dengan menggunakan metode diskusi, dimana masalahnya berasal dari peserta workshop[11].

\section{Solusi/ Teknologi}

Kami memberikan solusi berupa pelaksanaan workshop dengan materi pembuatan proposal dan laporan penelitian tindakan kelas untuk guru guru SD di Kecamatan Pasaman. Tujuannya adalah agar guru memiliki kemampuan menyelesaikan permasalahan di kelas dengan penelitian, tanpa mengesampingkan dokumentasi pelaksanaan kegiatan penelitian, berupa proposal dan laporan.
Pemecahan masalah yang timbul sesuai dengan yang tertera pada bagian pendahuluan menjadi pokok dasar pemecahan masalah. Tim pengabdian menemui pimpinan yang bertanggung jawab di Kecamatan Pasaman, Sumatera Barat untuk mendapatkan izin pelaksanaan kegiatan dengan mempertimbangkan keadaan sekolah. Setelah izin dan rencana jadwal disusun dengan baik maka tim pengabdian berdiskusi dengan tujuan menemukan materi dan pemateri yang sekiranya tepat untuk menjadi instruktur workshop. Pada tanggal yang telah disesuaikan maka pelaksanaan workshop diadakan.

Lokasi pelaksanaan kegiatan adalah gedung sekolah SD Negeri 23 Pasaman, pelaksanaan kegiatan tepat berada pada gedung tersebut. Total peserta adalah 40 orang, yang berasal dari beberapa sekolah lainnya di sekitar. Selain tim pengabdi sebagai instruktur, Kami juga mengundang pakar Penelitian Tindakan Kelas dari Universitas Negeri Padang, Drs. Syukri S.

Metode pelaksanaan workshop adalah dengan presentasi, pemodelan dan simulasi disertai tugas. Presentasi merupakan sebuah metode penyampaian materi secara sistematis oleh presentator tanpa menggunakan banyak media[12]. Bahan presentasi adalah tentang penelitian secara umum, dan penelitian tindakan kelas secara khusus. Kemudian instruktur berdiskusi dengan guru-guru, dengan memberikan contoh-contoh penelitian tindakan kelas yang telah selesai oleh peneliti-peneliti sebelumnya. Metode pemodelan merupakan metode memberikan contoh-contoh kepada peserta sehingga mereka dapat menirunya[13]. Serta tim meminta guru untuk mendesain proposal dan laporan penelitian tindakan kelas mereka sendiri. Metode penugasan adalah metode memberikan tugas kepada peserta agar dapat dikerjakan diluar waktu workshop[14]. Instruktur menilai hasil kerja guru. Pada tahap akhir, guru diberikan angket kepuasan untuk menghitung feedback guru terhadap pelaksanaan workshop.

\section{Hasil dan Diskusi}

Hasil angket kepuasan dari guru terhadap pelaksanaan workshop Kami sajikan pada gambar 1 berikut ini. 


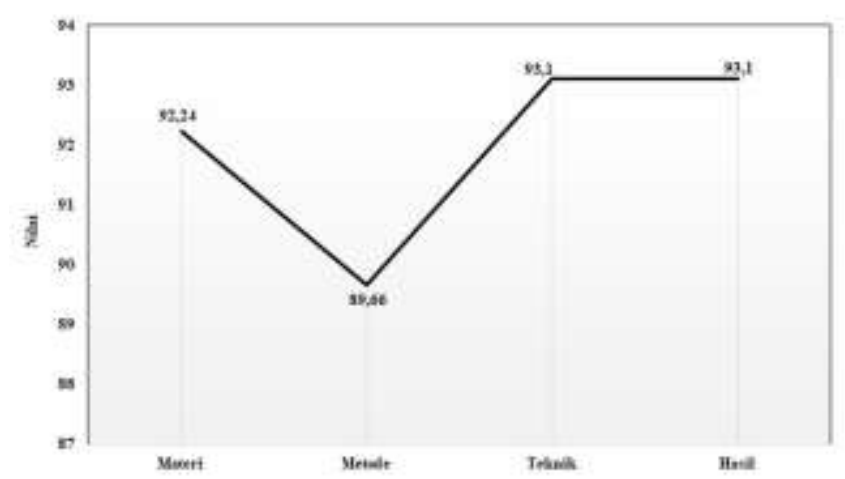

Gambar 1. Sebaran nilai angket kepuasan guru

Pengumpulan data menggunakan teknik angket. Angket merupakan serangkaian pertanyaan-pertanyaan tertulis yang diberikan kepada peserta workshop[15]. Angket terdiri atas 20 pertanyaan yang terbagi menjadi 4 kategori, yakni tentang materi kegiatan, metode, teknik, dan hasil. Guru diminta masing-masing untuk mengisi angket tersebut sesuai dengan keadaan sebenarnya. Penilaian terhadap materi workshop terkait tentang isi presentasi dan ilmu yang diberikan instruktur. Penilaian metode dan teknik workshop terkait dengan pelaksanaan kegiatan. Prosedur kegiatan yang sistematis dan rencana pencapaian tujuan kegiatan. Serta terkait hasil workshop, guru diminta memberikan penilaian tentang produk yang direncanakan dibuat, apakah sesuai atau tidak. Kemudian tentang produk yang dihasilkan apakah dapat menjadi contoh untuk guru membuat proposal dan laporan penelitian tindakan kelas selanjutnya. Nilai maksimal capaian dalam angket tersebut adalah 100.

Pada Gambar 1 tampak nilai-nilai yang diberikan guru melalui angket terhadap masingmasing indikator penilaian. Nilai tersebut adalah rata-rata dari setiap item pertanyaan. Materi workshop mendapatkan nilai 92,24, metode mendapatkan nilai 89,66, dan teknis serta hasil workshop mendapatkan nilai 93,10.

Nilai 92,24 pada indikator materi berarti dengan materi yang disampaikan selama workshop, guru dapat memahami dengan baik cara melakukan penelitian tindakan kelas, termasuk cara untuk menyusun proposal dan laporannya. Materi yang disampaikan dapat dengan mudah dipahami, karena materi tersebut adalah sesuatu yang baru bagi guru, dan menambah pengetahuan bagi guru. Materi juga mudah dipahami karena materi tersebut bersifat konkret[16].

Nilai untuk metode sebesar 89,66 dan teknik pelaksanaan sebesar 93,10 adalah nilai yang sangat baik untuk pelaksanaan kegiatan. Prosedur yang direncakan, prosedur yang dilaksanakan dan prosedur penilaian yang digunakan disenangi oleh guru, sehingga guru sangat puas. Materi yang mudah diserap oleh guru dikarenakan materi tersebut disampaikan dengan cara yang ringan dan mudah dipahami. Instruktur menyampaikan materi dengan metode diskusi kelompok kecil, setelah didahului dengan presentasi kelas. Memberikan penugasan dapat meningkatkan kemampuan guru, karena dengan penugasan dapat diketahui bagian-bagian workshop yang dipahami dan tidak dipahami.

Hasil workshop diberikan nilai sebesar 93,10. Produk yang dihasilkan guru berupa proposal dan laporan penelitian dapat menjadi contoh bagi guru untuk menyusun dokumentasi pada penelitian selanjutnya. Produk yang dihasilkan dan dinilai ini memberikan pengaruh yang cukup berarti terhadap guru. Awalnya guru tidak mengetahui bagaimana bentuk proposal dan laporan penelitian tindakan kelas, namun setelah melihat produk yang dibuat dan dikembangkan sendiri maka guru menjadi lebih terbuka pengetahuannya, serta merasa kemampuannya meningkat.

Workshop ini membuat guru menjadi lebih paham tentang cara, teknik dan segala sesuatu tentang penelitian tindakan kelas. Harapan Kami adalah munculnya rasa ingin tahu bagi guru sehingga tumbuh motivasi guru untuk mengamati permasalahan di kelas, mencarikan solusi untuk permasalahan tersebut, dan mendokumentasikan kegiatan penelitian. Motivasi guru menjadi pangkal untuk bangkitnya motivasi siswa[17]. Guru kemudian sadar bahwa kualitas pembelajaran merupakan tanggung jawabnya sebagai seorang profesional.

\section{Kesimpulan}

Workshop yang telah Kami laksanakan ini menghasilkan guru yang lebih berkompeten untuk melaksanakan penelitian tindakan kelas 
dan mendokumentasikannya. Kemampuan guru untuk menulis-pun meningkat. Selayaknya kemampuan guru ini akan meningkatkan pula kualitas pembelajaran, karena solusi sebuah permasalahan tidak akan ditemukan tanpa ada tahapan ilmiah untuk menyelesaikannya. Pelaksanaan workshop ini dapat menjadi dasar untuk pengembangan kegiatan selanjutnya.

\section{Ucapan Terima Kasih}

Kami mengucapkan terima kasih kepada Bapak Drs. Syukri S, yang telah menyediakan waktu dan kesempatan untuk berbagi ilmu dengan semua peserta. Ucapan terima kasih juga untuk pimpinan lembaga pendidikan di lingkungan Kecamatan Pasaman, camat dan kepala sekolah yang telah memberikan izin kepada pelaksanaan workshop. Juga ucapan terima kasih kepada seluruh guru yang berkesempatan hadir menunjang berhasilnya kegiatan pengabdian. Terakhir untuk seluruh tim pengabdian yang telah bekerja keras semaksimal mungking agar kegiatan ini terlaksana dengan baik, sampai pada publikasi hasil pengabdian.

\section{Pustaka}

[1] Rachmayani D. Penerapan Pembelajaran Reciprocal Teaching untuk Meningkatkan Kemampuan Komunikasi Matematis dan Kemandirian Belajar Matematika Siswa. J Pendidik Unsika 2014;2.

[2] Ardiansyah MP, Fauzi A, Yulkifli Y. Analisis Kesesuaian Materi IPA dengan Tujuan Kurikulum pada Buku Teks Pelajaran IPA SMP/MTs Kelas VIII Semester 1 untuk Diintegrasikan dengan Materi Banjir. Pillar Phys Educ 2019;12.

[3] Siregar NR. Persepsi siswa pada pelajaran matematika: studi pendahuluan pada siswa yang menyenangi game. Pros. Temu Ilm. Nas. X Ikat. Psikol. Perkemb. Indones., vol. 1, 2017.

[4] Noviyanti AK, Setyaningtyas EW. Partisipasi Pembelajaran Siswa Dalam Pembelajaran Dengan Classroom Rules. J Educ Res Eval 2017;1:65-72.

[5] Kusuma MA. Penerapan Model Pembelajaran Kooperatif Tipe Number Head Together Dengan Alat Peraga Materi Bangun Ruang Kubus Dan Balok Pada Peserta Didik SMP Darul Ulum Muncar. JPM J Pendidik Mat
2019;5:16-27.

[6] Hamid A. Guru Profesional. Al-Falah J Ilm Keislam Dan Kemasyarakatan 2017;17:27485.

[7] Sanjaya W. Penelitian Tindakan Kelas. Prenada Media; 2016.

[8] Hunaepi H, Prayogi S, Samsuri T, Firdaus L, Fitriani H, Asy'ari M. Pelatihan Penelitian Tindakan Kelas (PTK) Dan Teknik Penulisan Karya Ilmiah Bagi Guru Di Mts. Nw Mertaknao. Lumbung Inov J Pengabdi Kpd Masy 2016;1:38-40.

[9] Gunada IW, Harjono A, Gunawan G. Pelatihan Mendesain Penelitian Tindakan Kelas dan Pengembangan Model Dick and Carey Bagi Guru Guru di SMA Negeri 1 Narmada. J Pendidik Dan Pengabdi Masy 2018;1.

[10] Sunaryo S. Minat Siswa Dalam Mengikuti Pembelajaran Pendidikan Jasmani Di SMP Negeri 2 Tempel Kab. Sleman Daerah Istimewa Yogyakarta. Pendidik Jasm Kesehat Dan Rekreasi 2016;5.

[11] Johannes J. Meningkatkan Kompetensi Profesional Guru Dalam Menyusun RPP Melalui Workshop. J Pena Edukasi 2018;5:958.

[12] Sukaedi S. Peningkatan Prestasi Belajar Pendidikan Kewarganegaraan dengan Metode Presentasi dan Diskusi Kelompok (Siswa Kelas III SDN Candijati 01 Arjasa). Pancar Pendidik 2017;5:21-30.

[13] Kirana C, Suwandi S, Anindyarini A. Penerapan Metode Pemodelanuntuk Meningkatkan Motivasi Belajar Dan Keterampilan Menulis Naskah Drama Siswa Kelas XI IPA 3 SMA Negeri Kebakkramat. Basastra 2015;3.

[14] Ismail M, Hadi MN, Sunaiyah S. Metode Penugasan Dalam Pembelajaran PAI. Edudeena 2017;1.

[15] Susilo BE. Analisis Kesulitan Belajar Mahasiswa Pada Materi Hal Sejajar, Bersilangan, Dan Tegak Lurus Dalam Mata Kuliah Geometri Ruang Ditinjau Dari Gaya Belajar Mahasiswa. Sosiohumaniora J Ilm Ilmu Sos Dan Hum 2017;3.

[16] Sari RM. Pengembangan Media Komik Matematika Debit pada Siswa Kelas V Sekolah Dasar 2018.

[17] Han J, Yin H. Teacher motivation: Definition, research development and implications for teachers. Cogent Educ 2016;3:1217819. 